\title{
The Influence of Liquidity Toward Capital Structure
}

\author{
Paramita Astriyani ${ }^{1}$ \\ Faculty of Economics and Business \\ Semarang University, Indonesia
}

\author{
Suhardjo Yohanes 2 \\ Faculty of Economics and Business \\ Semarang University, Indonesia
}

\section{Asri Marwan ${ }^{3}$ \\ Faculty of Economics and Business \\ Gadjah Mada University, Indonesia}

Surel : astriyanisandyaparamita@gmail.com
Globalization and technological developments in the business world, both in the industry are growing rapidly. Most of the manufacturing companies use the debt as their capital structure which can be seen from the fluctuation of debt to equity (DER) ratio in 2014-2017. This research aims to examine the influ ence of liquidity toward capital structure in manufacturing companies listed on the Indonesia Stock Exchange for the 2014-2018 period, which are grouped by the company size. The multiple linear regression analysis is used to test the hypothesis. The results of this research indicate that liquidity has a negative influence toward leverage, reflects that the higher the liquidity of a company, the lower the level of leverage and vice versa. There is a consistency between large and small companies regarding the effect of liquidity on leverage. Capital structure for large and small companies still choose internal funds as the first choice.

Keywords: Capital Structure; Liquidity; Large Companies; Small Companies.

\section{Pengaruh Likuiditas terhadap Struktur Modal}

\section{ABSTRAK}

Globalisasi dan perkembangan teknologi dalam dunia bisnis, baik di bidang industri berkembang pesat. Sebagian besar perusahaan manufaktur menggunakan hutang sebagai struktur modalnya yang tercermin pada fluktuasi rasio hutang terhadap ekuitas (DER) pada tahun 2014-2017. Penelitian ini bertujuan untuk menguji pengaruh likuiditas terhadap struktur modal pada perusahaan manufaktur yang terdaftar di Bursa Efek Indonesia periode 2014-2018 yang dikelompokkan berdasarkan ukuran perusahaan. Analisis regresi linier berganda digunakan untuk menguji hipotesis. Hasil penelitian ini menunjukkan bahwa likuiditas berpengaruh negatif terhadap leverage, menunjukkan bahwa semakin tinggi likuiditas suatu perusahaan maka semakin rendah tingkat leverage dan sebaliknya. Terdapat konsistensi antara perusahaan besar dan kecil mengenai pengaruh likuiditas terhadap leverage. Struktur modal pada perusahaan besar dan kecil masih memilih dana internal sebagai pilihan utama.

Kata Kunci: Struktur Modal; Likuiditas; Perusahaan Besar, Perusahaan Kecil.

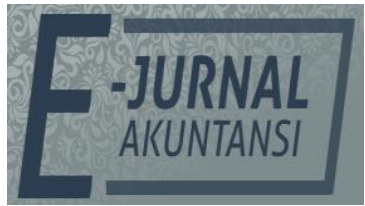

e-ISSN 2302-8556

Vol. 31 No. 11

Denpasar, November 2021

Hal. 2800-2811

DOI:

10.24843/EJA.2021.v31.i11.p10

PENGUTIPAN:

Astriyani, P., Yohanes, S., \&

Marwan, A. (2021). The

Influence of Liquidity

Toward Capital Structure. E-

Jurnal Akuntansi,

31(11), 2800-2811

RIWAYAT ARTIKEL:

Artikel Masuk:

18 Agustus 2021

Artikel Diterima:

25 November 2021

Artikel dapat diakses: https:/ / ojs.unud.ac.id/index.php/Akuntansi/index 


\section{PRELIMINARY}

Companies in Indonesia are mostly still using debt in their capital structure in a sizable portion (IDX Fact Book, 2014-2018). The manufacturing industry also chooses that their funding mostly comes from debt, which is reflected in the debt to equity ratio as shown in Table 1. Debt is a Source of funding other than internal funds in the form of retained earnings and equity. The use of high debt is not necessarily good or bad for the company because it depends on the benefits and costs arising from this debt. Capital structure is very important for the companies, especially manufacturing companies because it can affect some risks such as business risk and financial risk which in turn can affect value of the firm (Ehrhardt and Brigham, 2011). Therefore, company managers need to pay attention to their financing decision so that they can consider the optimal capital structure. The optimal capital structure is the structure that can maximize the value of the company or the value of its stocks.

Table 1. The Average DER of Manufacturing Companies in Indonesia by Sector 2014-2017

\begin{tabular}{cccc}
\hline \multirow{2}{*}{ Year } & \multicolumn{3}{c}{ Debt to Equity Ratio(DER) } \\
\cline { 2 - 4 } & $\begin{array}{c}\text { Basic Industry and } \\
\text { Chemicals }\end{array}$ & $\begin{array}{c}\text { Miscellaneous } \\
\text { Industry }\end{array}$ & $\begin{array}{c}\text { Consumer Goods } \\
\text { Industry }\end{array}$ \\
\hline 2014 & 1,68 & 1,11 & $-0,30$ \\
2015 & 1,48 & 1,67 & 0,97 \\
2016 & $-1,75$ & 1,71 & 0,89 \\
2017 & 1,06 & 1,68 & 1,62 \\
\hline
\end{tabular}

Source: IDX Fact Book, 2014-2018.

Companies need to pay attention to the factors that determine their capital structure. In the previous research conducted by Vo (2017), the liquidity variable is still used as a control variable. However, liquidity has an important role in determining the capital structure of a company. Thereis a research gapin previous research related to the direction of the relationship between liquidity and leverage. The liquidity ratio reflects the company's ability to meet its maturing (short-term) obligations using its current assets and reflects its financial position as internal funds. This creates a gap related to the relationship between liquidity and capital structure. According to Gunadhi and Putra (2019), liquidity has a negative effect on capital structure in accordance with the pecking order theory and agency theory. Companies with high levels of liquidity reflect higher current assets to finance the company's operational activities without having to use external Sources of funds in the form of debt. Companies prefer internal funds because they are safe and avoid swelling the company's cost of capital. However, the results of research conducted by Suherman et al. (2019) show that liquidity has a positive effect on the capital structure that supports the trade-off theory. The higher the level of company liquidity, the higher the company's capital structure because the use of leverage is higher.

The previous research conducted by Harc \& Sarlija (2012), Lipson \& Mortal (2009), Martynova \& Renneboog (2009), and Morellec (2001) have not distinguished companies based on company size. In this research, researchers have distinguished companies based on the size of the company, namely large companies and small companies to reduce bias. Besides, this research has used the 
liquidity variable as an independent variable and growth, tangibility as a control variable.

The capital structure is one of the things that need attention because it can affect the cost of capital to company efficiency. Theories regarding capital structure have been developed. Modigliani and Miller (MM) theory in 1958 explained that the firm value was not affected by its capital structure $\left(V_{U}=V_{L}\right)$ with the assumption that there were no agency costs, bankruptcy costs, taxes, absence of asymmetric information and the market was in perfect condition (Brigham \& Houston, 2007; Modigliani \& Miller, 1958). Modigliani and Miller (MM) theory in 1963 has modified the previous theory by adding an element of tax in it. The theory states that interest costs can be used as a tax deduction so that the tax element can add value to the company. However, MM II theory in 1963 uses the assumption that there is no bankruptcy costs. Modern theories regarding capital structurehave also been developed, such as the pecking order theory, agency theory, and tradeoff theory.

The pecking order theory states that companies prefer to use internal funds as their first choice of funding Sources (Myers, 1984). This is because internal funds are considered the cheapest and safest funds for the company. If internal funds are deemed insufficient, the company can choose external funds as an alternative, namely issuing debt and then equity. Agency theory explains the contractual relationship between principals (shareholders) who delegate authority for decision-making to agents called agency relationships (Jensen and Meckling, 1976). Managers will manipulate liquid assets by increasing agency costs which are high enough so that creditors tend to reduce the limit of financing available to the company. This is done to provide benefits for shareholders so that there is a transfer of wealth from creditors to shareholders (Myers and Rajan, 1998).

The trade-off theory states that a company will decide to increase its debt to a certain level when the tax savings (tax shields) for additional debt are the same as the cost of financial distress to increase firm value to an optimum point (Myers, 2001). However, after exceeding theoptimum point, an increase in debt will reduce the value of the company because the costs or burdens caused by financial distress and agency costs are greater than the benefits of tax savings.

Each company has a difference in the level of liquidity because one of them is influenced by the size of the company. Smaller companies tend to have a higher level of liquidity than large companies which can affect the level of leverage. Larger companies tend to have higher leverage than smaller companies. However, for both large and small company sizes, there is consistency in results, namely, liquidity has a negative influence toward leverage. The results of research by Bilgin and Dinc (2019), Deesomsak et al. (2004), Harc and Sarlija (2012), Lipson and Mortal (2009), Udomsirikul et al. (2011) also show that liquidity has a negative influence toward leverage. Therefore, the hypothesis in this research is Hypothesis. Liquidity has a negative influence toward leverage. The research model can be seen in Figure 1. 


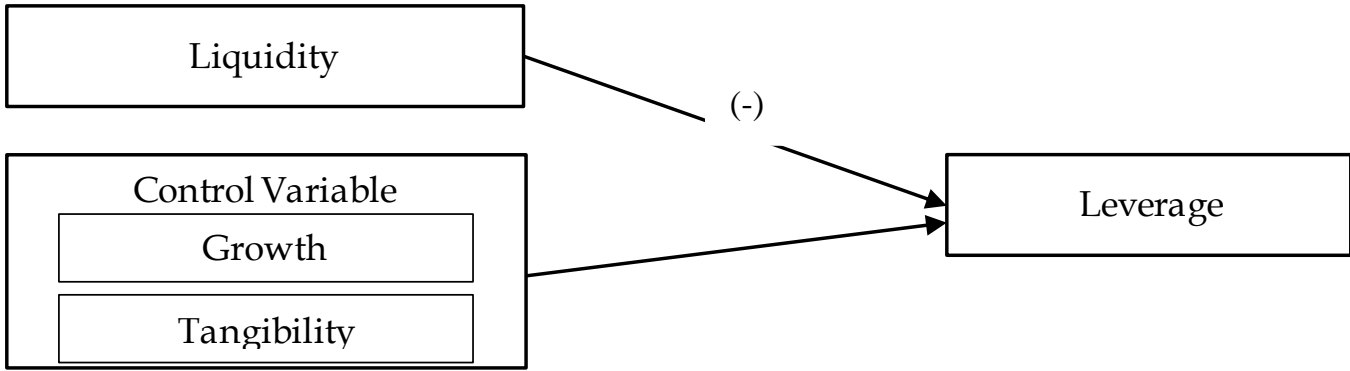

Figure 1. Research Model

Source: Research Data, 2020

This research aims to fill the gap by examining the influence of liquidity toward capital structure as measured by the leverage ratio based on the size of the company. Liquidity has a negative influence toward capital structure as measured by leverage. The higher the company's liquidity level, the more it will reduce the level of leverage. This is in accordance with the pecking order theory which states that companies tend to use internal funds first compared toleverage (Myers, 1984). The negative influence between liquidity and leverage is also supported by agency theory which states that companies will reduce debt and prefer to use internal funds first because of high agency costs (Myers and Rajan, 1998). On the other hand, liquidity has a positive effect on capital structure. The higher level of liquidity will reflect a higher ability to meet its debts at maturity which causes companies to prefer debt. This is supported by the trade-off theory which states that debt can reduce taxes so that companies are more likely to increase debt. The difference in the influence between liquidity and capital structure becomes a gap that needs to be re-examined, so this study aims to confirm previous theories and research.

This research is grouped by firm size because large companies and small companies have different levels of liquidity and leverage (Titman and Wessels, 1988). This paper discusses the liquidity as one of the determinants of financing decision that influences capital structure and the consistency of results between large and small companies. This research used a collection of financial data from manufacturing companies that have been listed on the Indonesia Stock Exchange covering the period 2014 to 2018. This research uses multiple linear regression analyses to solve existing problems. This paper contributes to the literature by examining the influence of determinants of capital structure, especially liquidity, on leverage in manufacturing companies listed on the Indonesia Stock Exchange. The manufacturing industry was chosen because most Indonesia companies are engaged in manufacturing and are a mainstay sector in bank lending (Statistik Perbankan Indonesia, 2019).

\section{RESEARCH METHODS}

This research uses a causal-explanatory study design with a quantitative approach. The data collection method uses a literature study such as financial reports or annual reports from the Indonesia Stock Exchange and the company's official website. The population in this research are companies in manufacturing that have been listed on the Indonesia Stock Exchange. The sample selection process in this research used a purposive sampling method which can be seen in Table 2 . 


\section{Table 2. Sample Selection Process Based on Criteria}

\begin{tabular}{lc}
\hline \multicolumn{1}{c}{ Criteria } & Total \\
\hline Companies engaged in manufacturing listed on the Indonesia Stock & 185 \\
$\begin{array}{l}\text { Exchange } \\
\text { Companies that do not publish complete and delisted annual financial }\end{array}$ & $(67)$ \\
$\begin{array}{l}\text { reports in the 2014-2018 period } \\
\text { Companies that donot present financialstatements in Rupiah }\end{array}$ & $(28)$ \\
\hline
\end{tabular}
Source: ResearchData,2020.

Companies are divided into two according to firm size, namely large and small companies. Large companies also usually make more use of external funds to meet their funding needs because they have a smaller credit risk (default) than smaller companies (Titman and Wessels, 1988). This research is designed to differentiate the manufacturing companies based on firm size, namely large and small companies with a proportion of $20 \%$ each. Based on the type of pooled crosssectional data, the number of observations for each subsample is 90 data observations.

The research instrument consisted of several variables, including the dependent, independent, and control variables. The dependent variable used is the capital structure as measured by the leverage ratio. The leverage ratio shows how a company finances its assets both for investment and for meeting its needs (Ehrhardt and Brigham, 2011). The leverage ratio as the dependent variable can be measured by the debt to equity ratio (DER). DER is used to assess how much funding is financed by debt.

$$
\text { Debt to Equity Ratio }=\frac{\text { Total Debt }}{\text { Total Equity }}
$$

The independent variable in this research is liquidity as measured by the current ratio. Liquidity is one of the company's funding alternatives because it is included as an internal Source of funds. The liquidity ratio as an independent variable is measured by the current ratio, which is the ratio of current assets to current liabilities (Brealey et al., 2015). Companies with low current ratios tend to have high leverage (Bilgin and Dinc, 2019).

$$
\text { Current Ratio }=\frac{\text { Current Assets }}{\text { Current Liabilities }}
$$

This study uses a control variable that aims to control the relationsiup between the independent variable and the dependent variable which is thought to have an effect on the dependent variable. Growth and tangibility are important factors that can influence the capital structure (Nita Septiani and Suaryana, 2018). This study focuses on the effect of liquidity on capital structure, so that factors that can affect capital structure other than liquidity need to be controlled. This is because the growth and tangibility variables can interfere with the results of the liquidity variable testing. Therefore, the control variables in this study are growth and tangibility. The use of control variables aims to avoid the occurrence of errors in the specification of the empirical model used in this study and to avoid biased calculation results .

Growth is a growth opportunity for a company in the future. The value of Tobin's Q ratio shows the conditions related to investment opportunities or the potential for growth of the company and shows the market value and investors' 
assessment of the company (Brainard and Tobin, 1968; Rajan and Zingales, 1995; Tobin, 1969). Therefore, Tobin's Q can be used as a proxy for growth. The higher the growth opportunities, the more incentives for the company to expand its business so that it tends to use external funds.

$$
\text { Growth }=\frac{\text { (Total Market Value }+ \text { Total Book Value of Liabilities) }}{\text { Total BookValue of Assets }}
$$

The tangibility ratio shows the number of fixed assets to the total assets of the company. The higher the tangible assets, the easier it is for the company to obtain external funding, which causes leverage to increase. Most companies in the manufacturing sector have capital in the form of fixed assets to support their production activities so that they can be used as debt collateral. Tangibility can be measured using the ratio of fixed assets to total assets.

$$
\text { Tangibility }=\frac{\text { Fixed Assets }}{\text { Total Assets }}
$$

The data analysis method used is multiple linear regression model. purpose of regression analysis is to use the data to be on the most line so that it can represent the relationship between variables using the least squares principle. The least square estimator needs to fulfill several assumptions, one of which is the Best Linear Unbiased Estimator (BLUE) assumptions or often known as the classical assumption test in accordance with the Gauss-Markov theorem (Gujarati, 2004: 79). Multiple linear regression analysis was used to determine the effect of liquidity, growth, and tangibility variables on leverage in manufacturing companies listed on the Indonesia Stock Exchange. The significance level used is $0.05(\alpha=5 \%)$. follows.

The equation of the multiple linear regression model in this research is as

Leverage $=a-\beta_{1}$ Liquidity $+\beta_{2}$ Growth $+\beta_{3}$ Tangibility $+\varepsilon$

\section{RESULT AND DISCUSSION}

The number of data sampled in this research is 90 companies. The total sample companies are then grouped into two sub-samples based on the size of the company according to the company's total assets. The categorization is done to find out about the effect of liquidity on funding decisions (leverage) based on the two categories with the assumption of getting the same results. In this research, there were 18 companies in the large company category and 18 companies in the small company category during the 2014-2018 period. The description of the data related to the results of descriptive statistics that aim to describe the characteristics of the sample can be seen in Table 3. 
Table 3. Descriptive Statistics Test Results

\begin{tabular}{|c|c|c|c|c|c|c|c|c|c|}
\hline \multirow[b]{2}{*}{ Variabel } & \multirow[b]{2}{*}{$\mathrm{N}$} & \multicolumn{4}{|c|}{ Large Companies } & \multicolumn{4}{|c|}{ Small Companies } \\
\hline & & Min & Max & Mean & $\begin{array}{l}\text { Std. } \\
\text { Dev }\end{array}$ & Min & Max & Mean & $\begin{array}{l}\text { Std. } \\
\text { Dev }\end{array}$ \\
\hline Leverage & 90 & 0,153 & 2,967 & 1,158 & 0,811 & 0,161 & 1,872 & 0,630 & 0,375 \\
\hline Liquidity & 90 & 0,267 & 6,567 & 1,989 & 1,264 & 0,450 & 6,502 & 2,583 & 1,430 \\
\hline Growth & 90 & 0,737 & 23,286 & 3,540 & 4,574 & 0,421 & 5,757 & 1,109 & 0,965 \\
\hline Tangibility & 90 & 0,188 & 0,877 & 0,538 & 0,157 & 0,136 & 0,801 & 0,400 & 0,164 \\
\hline $\begin{array}{l}\text { Valid N } \\
\text { (listwise) }\end{array}$ & 90 & & & & & & & & \\
\hline
\end{tabular}

Source: Research Data, 2020

Classical assumption testing in this research includes normality test, multicollinearity test and heteroscedasticity test. The normality test used in this research is Kolmogorov-Smirnov (KS). The results of the Kologorov-Smirnov test can be seen in Table 4.

Table 4. Normality Test Results

\begin{tabular}{ccc}
\hline & Large Companies & Small Companies \\
\hline Kolmogorov-Smirnov Z & 1,175 & 0,971 \\
Asymp.Sig. & 0,127 & 0,303 \\
& Normal & Normal \\
\hline
\end{tabular}

Source: Research Data, 2020

Based on Table 4, it shows that the asymp.sig (2-tailed) value for both large companies $(0.127>0.05)$ and small companies $(0.303>0.05)$ is greater than $(0.05)$ so that the data is normally distributed.

Multicollinearity test to test whether or not there is a correlation between one independent variable and other independent variables in the regression model. The results of the multicollinearity test in this research can be seen in Table 5 .

Table 5. Multicollinearity Test Results

\begin{tabular}{lccccl}
\hline \multirow{2}{*}{ Variable } & \multicolumn{2}{c}{ Large Companies } & \multicolumn{2}{c}{ Small Companies } & \\
\cline { 2 - 5 } & Tolerance & VIF & Tolerance & VIF & \\
\hline Liquidity & 0,562 & 1,779 & 0,599 & 1,670 & No multicollinearity \\
Growth & 0,905 & 1,105 & 0,961 & 1,040 & No multicollinearity \\
Tangibility & 0,523 & 1,912 & 0,586 & 1,706 & No multicollinearity \\
\hline
\end{tabular}

Source: ResearchData, 2020

Based on Table 5, shows that there is no symptom of multicollinearity from the regression model which is indicated by a tolerance value greater than 0.10 and a VIF (variant inflation factor) less than 10.

Heteroscedasticity test was conducted to show that a regression model did not have the same variance from one observation to another. Spearman's rank correlation test is used to detect the presence of heteroscedasticity, the results of which can be seen in Table 6 . 
Table 6. Test Result the Spearman's Rank Correlation

\begin{tabular}{llllll}
\hline \multirow{2}{*}{$\begin{array}{l}\text { Spearman' } \\
\text { s rho }\end{array}$} & \multicolumn{2}{c}{ Large Companies } & \multicolumn{2}{c}{ Small Companies } & \\
\cline { 2 - 4 } & \multicolumn{2}{c}{$\begin{array}{c}\text { Unstandardized } \\
\text { Residual }\end{array}$} & \multicolumn{2}{c}{$\begin{array}{c}\text { Unstandardized } \\
\text { Residual }\end{array}$} & \\
\hline Likuiditas & $-0,077$ & 0,469 & $-0,059$ & 0,580 & \\
Coefrelation & Sig. & $\begin{array}{c}\text { Correlation } \\
\text { Coeff. }\end{array}$ & Sig. & $\begin{array}{c}\text { No } \\
\text { heteroscedasticity } \\
\text { No }\end{array}$ \\
Growth & $-0,195$ & 0,065 & 0,140 & 0,187 & $\begin{array}{c}\text { heteroscedasticity } \\
\text { No }\end{array}$ \\
Tangibility & $-0,050$ & 0,638 & $-0,09$ & 0,935 & heteroscedasticity \\
\hline
\end{tabular}

Source: Research Data, 2020

The results of Spearman's rank correlation test based on Table 6 show that the value of significance in large and small companies has a value greater than 0.05 (sign. > 0.05) so that the regression model of this study has no symptoms of heteroscedasticity. The significance level of this research was $0.05(\alpha=5 \%)$.

Table 7. Test Result the Multiple Regression

\begin{tabular}{|c|c|c|c|c|c|c|}
\hline \multirow{3}{*}{ Variable } & \multicolumn{3}{|c|}{ Large Companies } & \multicolumn{3}{|c|}{ Small Companies } \\
\hline & \multicolumn{2}{|c|}{$\begin{array}{l}\text { Unstandardized } \\
\text { Coeff. }\end{array}$} & \multirow[t]{2}{*}{$\begin{array}{l}\text { Standardized } \\
\text { Coeff. }\end{array}$} & \multicolumn{2}{|c|}{$\begin{array}{l}\text { Unstandardized } \\
\text { Coeff. }\end{array}$} & \multirow[t]{2}{*}{$\begin{array}{c}\text { Standardized } \\
\text { Coeff. }\end{array}$} \\
\hline & $\mathrm{B}$ & Std. Error & & $\mathrm{B}$ & Std. Error & \\
\hline (Constant) & 2,382 & 0,435 & & 1,444 & 0,133 & \\
\hline Liquidity & $-0,475$ & 0,069 & $-0,741$ & $-0,239$ & 0,023 & $-0,911$ \\
\hline Growth & 0,022 & 0,015 & 0,123 & 0,008 & 0,026 & 0,020 \\
\hline Tangibility & $-0,662$ & 0,578 & $-0,128$ & $-0,514$ & 0,200 & $-0,224$ \\
\hline \multicolumn{7}{|c|}{ Dependent Variable: Leverage } \\
\hline
\end{tabular}

Source: Research Data, 2020

Based on Table 7, the equations of the multiple linear regression model for large companies are as follows.

Leverage $=2,382-0,475$ Liquidity $+0,022$ Growth $-0,662$ Tangibility $+\varepsilon$

The equation of the multiple linear regression model for small companies is as follows.

Leverage $=1,444-0,239$ Liquidity $+0,008$ Growth $-0,514$ Tangibility $+\varepsilon$

A regression model needs to be tested for model feasibility (goodness of fit) in order to test the accuracy of the regression function on the sample when assessing the actual value. The regression model in this research has a good level of model suitability as reflected in the results of the F-statistics test, $t$ test, and adjusted $R^{2}$.

The F-test was carried out with a significance level of 5\% (0.05). Based on Table 8, large companies have an $\mathrm{F}_{\text {statistic }}$ value of 22.166 with an -value of 0.000 that has fulfilled the goodness of fit requirements. Critical $\mathrm{F}_{\text {table }}$ or $\mathrm{CV}_{0.05 ; 86: 3}$ in this research is 2.71 at $5 \%$ significance, then $F_{\text {statistics }}>F_{\text {table }}(22.166>2.71)$ with -value less than $0.05(0.00<0,05)$. The statistical value of a small company is 34,931 with an value of 0.000 . The results of the $F$ test have met the goodness of fit model requirements with $\mathrm{F}_{\text {table }}$ or $\mathrm{CV}_{0.05 ; 86 ; 3}$ of 2.71 at $5 \%$ significance, then $\mathrm{F}_{\text {statistics }}>\mathrm{F}_{\text {table }}$ $(46.443>2.71)$ with value less than $0.05(0.00<0.05)$. Based on the result of F-test, 
it shows that liquidity, growth, and tangibility simultaneously affect leverage. These results were consistent for both large and small firms.

Adjusted $\mathrm{R}^{2}$ in this research shows that leverage can be explained by the three independent variables, namely liquidity, growth, and tangibility of $41.6 \%$ (large companies) and 60.5\% (small companies).

The t-test is carried out through a one-tailed test with a significance level of $5 \%$. Based on Table 6 , the liquidity variable in large companies has a $t_{\text {statistic }}$ value $>t_{\text {table }}(|-6.856|>1.633)$ with an -value of 0.000 less than a significance level of $0.05(0.00<0.05)$. Meanwhile, the liquidity variable in Table 6 shows that small companies have a $t_{\text {statistic value }}>t_{\text {table }}(|-10.578|>1.633)$ and the -value is smaller than the $5 \%$ significance level $(0.00<0.05)$. The results of the $t$-test show that the $\rho$-value of the liquidity variable is less than $5 \%(0.00<0.05)$, which means that liquidity in large and small companies has a negative and significant influence toward leverage. This supports the hypothesis that liquidity has a negative influence toward leverage.

Table 8. Test Result the Multiple Regression

\begin{tabular}{lcccccc}
\hline \multirow{2}{*}{ Variable } & \multicolumn{3}{c}{ Large Companies } & \multicolumn{3}{c}{ Small Companies } \\
\cline { 2 - 7 } & $\mathrm{t}_{\text {statistic }}$ & Sig. & $\mathrm{t}_{\text {statistic }}$ & Sig. & \\
\hline (Constant) & 5.481 & 0.000 & 10.847 & 0.000 & \\
Liquidity & -6.856 & 0.000 & H is & -10.578 & 0.000 & H is \\
& & & supported & & & supported \\
Growth & 1.450 & 0.151 & & 0.296 & 0.768 & \\
Tangibility & -1.145 & 0.256 & -2.574 & 0.012 & \\
$\mathrm{~F}_{\text {stat }}$ & & 22.166 & & 46.443 & \\
Sign. Fstat & $0.000 \mathrm{~b}$ & & $0.000 \mathrm{~b}$ & \\
Adj. $\mathrm{R}^{2}$ & & 0.416 & & 0.605 & \\
\hline
\end{tabular}

Source: ResearchData, 2020

Based on the test results, the hypothesis in this study is supported. Liquidity has a negative influence toward leverage in large and small companies in the manufacturing sector listed on the Indonesia Stock Exchange during the 2014-2018 period. The higher the level of company liquidity, the lower the level of leverage so that the capital structure decreases. The research results also prove the consistency of results in large and small companies. The results of these studies support the results of research conducted by Bilgin \& Dinc (2019), Dewiningrat \& Mustanda (2020), Harc \& Sarlija (2012), Lipson \& Mortal, (2009), and Udomsirikul et al. (2011) found that there is a negative influence between liquidity and leverage. The results of this research also support the pecking order theory which states that companies prefer to use internal funds first than external funds to finance their operational activities. Companies that have high liquidity reflect that the company has current/ liquid assets so that it can finance its operations without having to use external Sources of funds so as to reduce debt levels. The element of uncertainty in the future that is getting higher and expensiveexternal financing makes companies increase the liquidity of their assets and reduce external financing such as debt. In addition, using external funds is considered safer and avoids swelling the company's capital costs. The results of the study are also in accordance with the agency theory which states that the use of debt will reduce the share of shareholder profits because it is given to creditors. Therefore, companies prefer to use internal funds rather than using debt. 
The test results of manufacturing companies that have been listed on the Indonesia Stock Exchange for large company groups indicate that liquidity has a negative influence toward capital structure or leverage in particular. If the liquidity of large companies is getting lower, the decision on funding with leverage will be higher. Large companies tend to have a lower level of liquidity than small companies, making large companies need to find additional external funds. The level of leverage in large companies is higher because it tends to have easier access to the market, is more transparent, has less credit risk, is more resilient when hit by a crisis, and has low agency costs. Also, internal funds of large companies are not can cover the entire fund to finance investment or its needs so that it uses additional external funds in the form of debt. However, large companies still use internal funds as their first choice. The lower the liquidity of a company, it will choose to use debt (leverage) in its capital structure.

In small companies, liquidity also has a negative influence toward leverage. If the liquidity of the company is higher, the decision on funding with leverage will be lower. High liquidity also reflects high internal funds. In Indonesia, thecost of financing external funds is considered expensive. Therefore, small companies tend to use internal funds to finance investment and other needs. Small companies have higher liquidity than large companies because they have more current assets so they can be converted into cash more quickly. Small companies usually maintain the level of liquidity to improve their company's performance so that they get the trust of various parties. The higher the level of liquidity, the more likely it is to use internal funds in financing decisions first.

\section{CONCLUSION}

Based on the analysis and discussion, the capital structure in the manufacturing sector that have been listed on the Indonesia Stock Exchange is influenced by liquidity. There is consistency in the results of research, namely, liquidity has a negative influence toward leverage in large and small companies. The higher the level of liquidity, the smaller the level of company leverage and vice versa. The research results are also following the pecking order theory and agency theory. Limitations that can affect the results of the research are proxy leverage only looks at the debt to equity ratio and other independent variables used only liquidity, growth, and tangibility. Another limitation is the observation period uses only five years, so it shows fewer results in the long term. In addition, the analytical method still uses multiple linear regression, not using panel data regression.

Based on the conclusions and limitations, the suggestions in this research are for issuers in this research, it can be a suggestion for making corporate capital structure. It is necessary to implement various capital structure theories so that the company can minimize risks and costs arising from external financing. For further researchers, they can carry out tests related to capital structure theory by adding other variables and expanding the research period by adding years of observation, so that new phenomena and better results can be obtained. 


\section{REFERENCES}

Bilgin, R., \& Dinc, Y. (2019). Factoring as a Determinant of Capital Structure for Large Firms: Theoretical and Empirical Analysis. Borsa Istanbul Review, 19(3), 273-281. https://doi.org/10.1016/j.bir.2019.05.001

Brealey, R. A., Myers, S., \& Marcus, A. J. (2015). Fundamentals of Corporate Finance (Eighth). McGraw-Hill.

Brigham, E. F., \& Houston, J. F. (2007). Fundamentals of Financial Management (Eleventh). Thomson South-Western. https://lccn.loc.gov/2018046370

Deesomsak, R., Paudyal, K., \& Pescetto, G. (2004). The determinants of capital structure: Evidence from the Asia Pacific region. Journal of Multinational Financial Management, 14, 387-405. https:/ / doi.org/10.1016/j.mulfin.2004.03.001

Dewiningrat, A. I., \& Mustanda, I. K. (2020). Pengaruh Likuiditas, Profitabilitas, dan Pertumbuhan Aset Terhadap Struktur Modal. E-Jurnal Manajemen Unud, 2(3), 18-31. https://doi.org/10.32877/eb.v2i3.137

Ehrhardt, M. C., \& Brigham, E. F. (2011). Financial Management: Theory and Practice. In South-Western Cengage Learning (Thirtheent). South-Western Cengage Learning. https:// doi.org/10.1002/9781119057093.app4

Gujarati, D. N. (2004). Basic Econometrics (Fourth). McGraw-Hill.

Gunadhi, G. B. D., \& Putra, I. M. P. D. (2019). Pengaruh Profitabilitas, Struktur Aset, Likuiditas, Dan Pertumbuhan Penjualan Terhadap Struktur Modal Perusahaan Makanan Dan Minuman. E-Jurnal Akuntansi, 28, 641. https:/ / doi.org/10.24843/eja.2019.v28.i01.p25

Harc, M., \& Sarlija, N. (2012). The Impact of Liquidity on The Capital Structure: a Case Study of Croatian Firms. Business Systems Research, 3(1), 30-36. https:/ / doi.org/10.2478/v10305-012-0005-1

IDX Fact Book 2014. (2014).

IDX Fact Book 2018. (2018).

Jensen, C., \& Meckling, H. (1976). Theory of The Firm: Managerial Behavior, Agency Costs, and OwnershipStructure. Journal of Financial Economics, 3, 305360.

Lipson, M. L., \& Mortal, S. (2009). Liquidity and capital structure. Journal of Financial Markets, 12, 611-644. https:/ /doi.org/10.1016/j.finmar.2009.04.002

Martynova, M., \& Renneboog, L. (2009). What Determines The Financing Decision in Corporate Takeovers: Cost of Capital , Agency Problems, or The Means of Payment? Journal of Corporate Finance, 15(3), 290-315. https:/ / doi.org/10.1016/j.jcorpfin.2008.12.004

Modigliani, F., \& Miller, M. H. (1958). The Cost of Capital, Corporation Finance and the Theory of Investment. American Economic Association, 48(3), 261-297.

Morellec, E. (2001). Asset Liquidity, Capital Structure, and Secured Debt. Journal of Financial Economics, 61, 173-206.

Myers, S. C. (1984). The Capital Structure Puzzle. The Journal of Finance Journal, XXXIX(3), 575-591.

Myers, S. C. (2001). Capital Structure. Journal of Economics Perspectives, 15(2), 81102.

Myers, S. C., \& Rajan, R. G. (1998). The paradox of liquidity*. Quarterly Journal of Economics, August. 
Nita Septiani, N. P., \& Suaryana, I. G. N. A. (2018). Pengaruh Profitabilitas, Ukuran Perusahaan, Struktur Aset, Risiko Bisnis dan Likuiditas pada Struktur Modal. E-Jurnal Akuntansi, 22, 1682. https://doi.org/10.24843/ eja.2018.v22.i03.p02 Statistik Perbankan Indonesia (Vol. 18, Issue 1). (2019).

Suherman, Resy Purnamasari, \& Umi Mardiyanti. (2019). Pengaruh Struktur Aset, Likuiditas, dan Profitabilitas terhadap Struktur Modal Dimoderasi oleh Ukuran Perusahaan. Jurnal Ilmiah Manajemen, 9(2), 369-381. dx.doi.org/10.22441/mix.2019.v9i2.009

Titman, S., \& Wessels, R. (1988). The Determinants of Capital Structure Choice. The Journal of Finance, 43(1), 1-19. https://doi.org/10.1111/j.15406261.1988.tb02585.x

Udomsirikul, P., Jumreornvong, S., \& Jiraporn, P. (2011). Liquidity and Capital Structure: The Case of Thailand. Journal of Multinational Financial Management, 21, 106-117. https:// doi.org/10.1016/j.mulfin.2010.12.008

Vo, X. V. (2017). Determinants of Capital Structure in Emerging Markets: Evidence from Vietnam. Research in International Business and Finance, 40, 105-113. https:/ / doi.org/10.1016/j.ribaf.2016.12.001 